\title{
The relationship between organizational Values and Propensity to Export in Industrial town of Sanandaj (No.2)
}

\author{
Shojaei Abdel Nasser, Fadakar Ahmad \\ Department of Business Management, Islamic Azad University. Sanandaj Branch, Sanandaj, Iran \\ E-mail address: fadakar82@gmail.com
}

\begin{abstract}
Keywords: Organizational values; Export Propensity; Sanandaj Manufacturing Firms; the Quality and Customer -Oriented Values
\end{abstract}

\begin{abstract}
This research investigates the relationship between organizational values and propensity. In the manufacturing Firms of Sanandaj the statistical population includes (No.2). Among these 1142 Cases were Chosen in this research, due to the nature of the research subject and Statistical population. Random Stratified Sampling was used and, based on Cochran formula 287 cases completed the questionnaire the research is descriptive correlational data was gathered by a verified questionnaire which a- Chronbach in the questionnaire included organizational value variable $(\mathrm{a}=/ 082)$. and in the questionnaire, the export propensity was $/ 084$ the regression analysis result show the control variable (export propensity), is affected at, first, from the variable of the values related to the quality and the consumers. This variable determine $30 \%$ of the variance of expert propensity among the studied population then, the control is affected variable from external social value variable this variable determine $29 \%$ of the export propensity variance among the studied population then, the control variable from external social value variable this variable determine $29 \%$ of the export propensity variance among the studied population. The third effective variable on export propensity is economic - Supportive Values Variables. This variable determined $\% 27$ of the export propensity variance among the studied population
\end{abstract}

\section{INTRODUCTION}

In most developed and developing countries, micro and medium Sized Firms play an important role in the economic, Based on the UN report introduced by Reynard and Forstater (2002), this firms Share $90 \%$ of the global businesses and take the responsibility of 50 to $60 \%$ of global job opportunity, in which the importance of this firms is increasing and take its way toward globalization? (Sentuki, Erdem, 2008: 171).

In turkey, micro and medium sized firms, 99/8 percent of the total firms, 76/7 percent of the recruitments, 38 Percent of the investments, $26 / 5$ percent of added value about $0 \%$ of exports and $5 \%$ of the bank credits is allocated. When it is compared with another country, this amount is small there is no exact statistics for these firms export in Iran But IF the companies want to remain in today competitive environment, they should pa clear attention to globalization and develop the products development globalization and develop the products, and export.

In the third and fourth program, export as an impressive component in economic development of the country and focus on cultural and the country and focus on cultural and social infrastructure to apply export strategies. Export development and proper entering the Steady Condition is not obtained, unless one Create a suitable explicit and Sustainable Strategy of export as a stable and concrete law and also the unions.

And export committees and commercial companies including banks, insurance, transportation, should do their best in this was and it is necessary the society become ready to manufacture the best products for export. Various variables have been detected and examined. Among these the export propensity and export of the firms, including innovation characteristics in the manufacturing part (Rodriguez, y, L. and R. M.G Rodriguez, (2005: 539), the skilled manager attendance in the firms and foreign language skills (Obben, j. and p. Magagula, 2003: 73). The activities of the research and development units' Lefebvre E, L. A Lefebvre and M. Bourgault, 1998: 365), Product Quality 
Brooks E. L, 2006: 106) and the other organizational variables. Another organizational variable which can be effective on the export propensity of the firms is organizational values. Organizational Values reflects the organizational belief and priorities belong to organizational form mission and ethic aspect, and acts as a guidance in managers decisions and the recent years, Organizations Face with many Changes. Among these challenge one can refer to attitude, knowledge, and Alignment with ethics and behaviors in the organization and management domain.

In addition to legal and organizational standards, the staffs and managers need some ethical and normative categories to help them in the organizational behaviors and actions make the path for them to reach a collective proper approach (Samdanian and Soltani 2011: 2) . Organizational values can play an impressive role on our analysis and refer to the concept of commitment, as a result the tendency toward working increase and consequently the productivity increase (Baigi Nia etal, 2013: 21). Also, applying organizational Values can improve the Staffs behaviors and professional ethics as basis for business the perfect organizations try to find behavioral odes Based on organizational Values Paying attention to quality and the needed bases in applying the norms and convert it into the operational behaviors it is pale Another research necessity is done with organizational values , Managers and organizational administrator and other related People give information about what is necessary for organization (Gol Prvar et al, 2009: 47)

Berry (1999) introduce it in organizational value importance, as heart and soul of organizations Based on Daltons, Report (2006). Organization (GOL PARVAR et, al , 2009:46).

Berry (1999) introduced it, in organizational Value importance, as Heart and soul of organizations. Based on Daltons Report (2006), organizational values and power in various Studies has been introduced as the antecedents of the various phenomena such as commitment, meta - role behaviors , performance, efficiency and organiztioonal effectiveness Gol parvar and Niri, 2010: 74). AS mentioned, the research aim is to determine the relationship between organizational values and export propensity in the manufacturing firms in Sanandaj Industrial Town (No. 2)

\section{THEORETICAL BASES}

Organizational Values refers to the Values which guide the Behaviors, Thoughts and attitude of organization managers and Staffs and effect on them. Organizational values are regarded as the main bases of Decision Making and act as a judgment Tools.

Organizational Values, are regarded as the factors which distinguish an global organization From Small and medium sized organizations, (Mohsen Vand, 2008: 2)

\subsection{The relationship between organizational}

Values and export propensity about Values, Various Definitions have been introduced values are regarded as the behaviors, in an organization, from the proper behaviors, and act as filter all the organizational derisions and operations pass through it on the other hand, the desires are formed by cognitive, emotional and behavioral parts, Meanwhile, organizational Values can form organizational behavior originated from people behavior in the organizations organizational Values have direct impact on the firms and organizational performance and also cause the good become the best (James , 2014) the relationship between organizational values with the Variables Such as job Satisfaction (Diskienes, D, \& Gostautas, V, 2011) team performance (Arthuard - day,) M.L , Rodebj, c, \& Turnley, w. h, 2012), Organizational Learning (Cohen, A, \& liu, y, 2011), Involvement, organizational commitment 2011), involvement, Organizational commitment (James, 2014) are mentioned in various (James , 2014) are mentioned in various related literature - so, organizational to get global fame or affirm tendency in developing its export affairs in various Studies the relationship between organizational culture variables and export propensity have been detected ( Dosoglu- Guner, ) $\mathrm{B}_{0}, 2001$ ). In some definitions the term organizational value is outstanding which form organizational behavior also

The customers; (2) human and developmental values; (3) the Involvement and human communication; (4) extra organization social value; (5) economic- supportive values and export propensity 


\section{METHODOLOGY}

The research is applicative and descriptive correlation. The The research statistical population include the staffs of Sannadj industrial town (No. 2). Among these, $114^{2}$ were chosen as statistical population In this research, according to the research subject nature and the study statistical population random stratified sampling was used. Based on Cochran formula, 287person completed the questionnaire. Data was gathered with a verified questionnaire. Data was gathered with a verified questionnaire, after affirming its validity and reliability, distributed among the respondents. To determine the questionnaire validity the content validity was used. In this research, the statistical tests were done with SPSS software.

\section{FINDINGS}

A: Descriptive research result Gender distribution, education and the samples activity status separately, shown as follows.

Table 1: The study distribution frequency based on the ground variables

\begin{tabular}{|l|l|l|l|}
\hline Variables & Variable & Frequency & Percentage \\
\hline & $\begin{array}{l}\text { Male } \\
\text { Female }\end{array}$ & $\begin{array}{l}378 \\
6\end{array}$ & $\begin{array}{l}98 / 4 \\
1 / 6\end{array}$ \\
\hline & $\begin{array}{l}\text { Diploma, under- } \\
\text { Diploma }\end{array}$ & 162 & $42 / 2$ \\
\hline Education & Technician & 100 & 26 \\
\hline & Expert & 116 & $30 / 2$ \\
\hline & $\begin{array}{l}\text { Post graduate and } \\
\text { more }\end{array}$ & 6 & $1 / 6$ \\
\hline & Under 5-yearsold 4 & 9 & $2 / 3$ \\
\hline & 5 to6 years old & 33 & $8 / 6$ \\
\hline & $11-15$ years old & 72 & $18 / 8$ \\
\hline & 16 -to 20 years & 97 & $33 / 2$ \\
\hline & More than 21 & 173 & $45 / 1$ \\
\hline
\end{tabular}

\subsection{Hypothesis test}

4.1.1. The main hypo thesis: There is significant relationship between organizational values and export propensity in the manufacturing firms of Sanandaj industrial tom (No. 2).

To test the hypo thesis Pierson significance test (r) was used. Clearly, the significance level $(\operatorname{sig}=0 / 000)$ was less than a-Chronbach $(a=0 / 05)$ show there was significance relationship between two variable. The correlation coefficient between two variables was positive direct $(0 / 341)$. So, ho was rejected But, H1 was affirmed. As a result, one can say the more organizational values observance is, the more propensities are observed toward export.

Table 2. Correlation test relationship between organizational values and its components and export propensity

\begin{tabular}{|l|l|l|}
\hline Independent Variable & & Control variables \\
\hline Significance & Pierson correlation coefficient & Variables \\
\hline $0 / 000$ & $0 / 341$ & Organizational values \\
\hline $0 / 000$ & $0 / 370$ & Quality and costumer values \\
\hline $0 / 000$ & $0 / 317$ & Human and growth values \\
\hline $0 / 000$ & $0 / 121$ & $\begin{array}{l}\text { Human relations values and } \\
\text { Invement }\end{array}$ \\
\hline $0 / 000$ & $0 / 374$ & Extra Organizational social values \\
\hline $0 / 000$ & $0 / 339$ & Economic-supportive values \\
\hline
\end{tabular}


Measurement model of determining factors in export propensity

To measure the mentioned model, from the research variables organizational values aspects was entered to the equation as independent variable.

Table 3. The related statistics to the independent variable remained in the regression model.

\begin{tabular}{|l|l|l|l|l|l|}
\hline Variable Name & $\mathrm{B}$ & Std.B & Beta & $\mathrm{T}$ & Sig T \\
\hline $\begin{array}{l}\text { Intercept values on customers and } \\
\text { quality }\end{array}$ & $0 / 205$ & $0 / 036$ & $0 / 297$ & $5 / 642$ & $0 / 000$ \\
\hline Extra organizational social values & $0 / 411$ & $0 / 074$ & $0 / 292$ & $5 / 544$ & $0 / 000$ \\
\hline Economic-supportive values & $0 / 885$ & $0 / 207$ & $0 / 266$ & $4 / 266$ & $0 / 000$ \\
\hline
\end{tabular}

As mentioned in the above figure, 3 dimensions of organizational value (quality and customer values, extra organization-social values- and economic-supportive values) remain in the model The influence of the dependent variable from independent variable follows:

1. Quality and customers' value: account for $30 \%$ of dependent variable variance

2. Extra Organization social values: account for $22 \%$ of defendant variable variance.

3 . Economic-supportive values: account for $27 \%$ of dependent variable variance.

The final model of multivariate analysis is as follows:

Export propensity $=41 / 033$ (customer values) $+0 / 44$ (Extra organization social value) $+0 / 885$ (economic-supportive values)

\section{CONCLUSION}

The research investigates the relationship between organizational values and export propensity in manufacturing firms of Sanandaj Industrial town (No.2). The result show there was positive, direct significant relationship among customer and quality values, human and developmental/growth value, human and developmental/growth value, human communication values and involvement. Extra organization social values, and economic -supportive values and export propensity. Organizational values have various benefits for the firms because and guides for decision-makings and behaviors coordination in life and survival shows a unique organization. It plays a fundamental role in staffs integration. It leads to organizational organic unity.

Are the basis of the trust and development in people organizations, determine the organization. To confirm the result of successful firms in the export and those who wanna take a position should try to be ethical responsive, and profitable toward the staffs. In an organization with real norms, there is only and boss and its values is organizational (David, 2004)

Based on the result suggestions are given as follows:

In forming and reviewing the policies and strategic programs of the firm and from the behavioral operational codes and indices should be exploited.

It is recommended, when the managers and directors recruit the staffs which their individual values have more compatibility with organizational values; they should override them, and try to improve organizational values through training before and during service can be effective in internalizing the organizational values.

\section{Reference}

[1] Beigi Nia, Abdol-Reza, Sardari, Ahmad, Ashurizade, Alireza., "the Relationship commitment, Al Mahdi Hormozgan province, Alluminium firm. Managemen Research in Iran, 17(2)(2013)19-41.

[2] David ford. R., "Strategic management" (15 ${ }^{\text {th }}$ edition), Translator: Ali parsian and Sayed Mohammad Erabi. Tehran: cultural Research office(2009).

[3] samdanian. Hamed and Soltani, Iraj .,Operational Behaviors based on organizational values in senior Manager Layers. Ethics in the science and Technology (2) (2011) 74-85. 
[4] Farhadi, Mohamafd, Barkhodari, Zainab.,"The Relationship between Organizational values and organizational Ethics". Ethics Research Letter, 20(2012)77-82.

[5] Golparvar, Mohsen; Niri, shirin and Mehded, Ali ., The Relationship between organizational value and job stress, Emotional Exhaustion, organization deviant Behaviors in steel company Employee. Knowledge and Research in pasychology 42(2009) 43-66.

[6] Nategh, Mohammad, Niakan, Nazila., " Strenghtening Export Development Emphasizing on Limiation, Stimulus, and Export performance. Commercial Review, 37(2009)43-55.

[7] Aaby, N.-E., \& Slater, S. F. , Management influences on export performance: a review of the empirical literature 1978-1988. International marketing review, 6(4)(1989).

[8] Arthaud-Day, M. L., Rode, J. C., \& Turnley, W. H., Direct and contextual effects of individual values on organizational citizenship behavior in teams. Journal of Applied Psychology, 97(4)(2012)792.

[9] Bansal, P., From issues to actions: The importance of individual concerns and organizational values in responding to natural environmental issues. Organization Science, 14(2003)510-527.

[10] Bourne, H., \& Jenkins, M., Organizational values: a dynamic perspective. Organization Studies, 34(4) (2013) 495-514.

[11] Brooks E. L., why don't Firms Export More? Product Quality and Colombian Plants, Journal of Development Economics, 80(2006)160- 178.

[12] Cohen, A., \& Liu, Y., Relationships between in-role performance and individual values, commitment, and organizational citizenship behavior among Israeli teachers. International Journal of Psychology, 46(4) (2011) 271-287.

[13] Colleya, S K., Jonathan L, Andrew N., An examination of the relationship amongst profiles of perceived organizational values, safety climate and safety outcomes, Safety Science , 51(2012)6976.

[14] Dylag A \& et al., Discrepancy between individual and organizational values: Occupational burnout and work engagement among white-collar workers, International Journal of Industrial Ergonomics,43(2013)225-231.

[15] Diskienè, D., \& Goštautas, V., Relationship between individual and organizational values and employees' job satisfaction. Verslo ir teisès aktualijos/Current Issues of Business and Law, 5(2)(2011) 295-319.

[16] Dosoglu-Guner, B., Can organizational behavior explain the export intention of firms? The effects of organizational culture and ownership type. International Business Review, 10(1) (2001)71-89.

[17] James, P., Aligning and Propagating Organizational Values. Procedia Economics and Finance, 11(2014) 95-109.

[18] Lefebvre E., L. A. Lefebvre and M. Bourgault., R\&D-Related Capabilities as Determinants of Export Performance, Small Business Economics, 10(1998)365-377.

[19] Obben, J. and P. Magagula., Firm and Managerial Determinants of the Export Propensity of Small and Medium-Sized Enterprises in Swaziland, International Small Business Journal, 21(1) (2003)73-91.

[20] Şentürk İ, Erdem C., Determinants of Export Propensity and Intensity of SMEs in Developing Countries: An Empirical Analysis of Turkish Firms, The Empirical Economics Letters, 7(2) (2008),ISSN 16818997 
[21] Michailovaa, Snejina \& Dana B. Minbaevab., Organizational values and knowledge sharing in multinational corporations: The Danisco case, International Business Review, 21(1) (2012)59-70.

[22] Raynard, P. \& M. Forstater .(2002). Corporate Social Responsibility: Implications for Small and Medium Enterprises in Developing Countries, United Nations Industrial Development Organization. http://www.unido.org/userfiles/BethkeK/csr.pdf (Access: 23.08.2007

[23] Rodriguez, J. L. \& R.M.G. Rodriguez. Technology and Export Behavior: A Resource-based View Approach, International Business Review, 14: 539-557. 